\title{
Derzhavin's Metaphysics of Morality
}

\section{Aaron BEaver}

In this essay, Aaron Beaver argues that the poetry of Gavrila Derzhavin routinely and consistently connects metaphysical beliefs with moral ones, and that, at its most sophisticated, this connection amounts to a full "metaphysics of morality" much like that developed by Derzhavin's contemporary, the philosopher Immanuel Kant. Beaver begins by exploring Derzhavin's belief in the immortality of virtue; he then examines how Derzhavin's famous monument poems assert the poet's immortality because he verbally pays tribute to those who are virtuous; finally he analyzes Derzhavin's 1797 poem "Bessmertie dushi," in which the poet realizes the connection between the immortality of the soul and morality. The latter part of the article examines Derzhavin's poetic expression of this connection in light of Kant's two postulates of the moral law-the immortality of the soul and the existence of God-and finds that Derzhavin's poetry expresses a similar position with genuine philosophical rigor.

\section{Dostoevskii's Geography: Centers, Peripheries, and Networks in Demons}

\section{ANNE LOUNSBERY}

Demons takes an infamous real-life Moscow event (the "Nechaev Affair") and moves it to a nameless provincial city. What can this geographic shift tell us about both Fedor Dostoevskii's novel and the particular vision of Russian geographic space that informs it? Anne Lounsbery argues that Demons' representation of the provinces responds to a certain imaginary geography of Russia, one that can locate meaning only in a center. The ideological implications of this geography are played out in Dostoevskii's representation of the railroad as a sinister and ever-widening network extending across a blank landscape. The interlocking rail lines "covering Russia like a spider web" reflect the provincial revolutionaries' paranoid political vision as well as their inability to see themselves as anything but tiny points on this network, insignificant without the web's power to connect them to a hub of meaning. Lounsbery relates Dostoevskii's geographic vision to patterns that structure the representation of Russian space in works by many nineteenth-century writers, including Nikolai Gogol', Mikhail Saltykov-Shchedrin, and Anton Chekhov.

\section{Unruly Felons and Civilizing Wives: Cultivating Marriage in the Siberian Exile System, 1822-1860}

\section{Abby M. Schrader}

In the late eighteenth and early nineteenth centuries, Russian imperial authorities advocated colonizing Siberia and linking it to the center. This process was difficult: not only was the region remote, but it also had a reputation for lawlessness that was intensified by the 1822 expansion of the 
exile system. In this article, Abby M. Schrader examines one attempt that authorities undertook to civilize Siberia. Attributing much of the disorder that prevailed in Siberia to the region's severe gender imbalance and lack of stable households, officials sought to promote marriage among banished men. In doing so, authorities laid bare important preconceptions about Russian women's socio-sexual role. Rather than perceiving women as agents, they saw them as tools that could be deployed to enhance the larger social order. Placing stock in the potential for women to settle Siberia's exiles also provided authorities with an opportunity to displace blame for the failure of their policies upon women.

\section{Story, Time and Dependent Nationhood in the Uzbek History Curriculum}

\section{Shoshana Keller}

In the 1950s the Soviet school system stabilized and teachers incorporated non-Russian national histories into the elementary curriculum. Shoshana Keller argues that in Soviet Uzbekistan teachers defined Uzbek nationhood partly through historical narrative, which told children that the Uzbek people had existed continuously from ancient times but the nation achieved independence only under Russian/Soviet leadership. Children learned that for millennia Uzbek hero/martyrs had fought losing battles against foreign invaders. The best Uzbeks were from the lower classes, but the nation had also produced high culture. Above all, children were taught to imagine themselves, not within Eurasian Islamic historical time, but within European historical time as envisioned by Karl Marx, Vladimir Lenin, and Iosif Stalin. What children learned about Uzbek history in school was central to the formation of a personal sense of national identity and to the larger Soviet project of nation building.

\section{Finding a Home for Television in the USSR, 1950-1970}

\section{KRISTIN ROTH-EY}

In this article, Kristin Roth-Ey explores the complex and often convoluted reception of television technology in the USSR of the 1950s and 1960s. Television held out the potential to fulfill the long-standing dream of a universal Soviet culture - propaganda, art, and science delivered directly to every home - and it offered a compelling symbol of a modern Soviet "way of life" in a Cold War context as well. Soviet consumers and technological enthusiasts embraced the new medium with gusto and played an important role in its promotion. As Roth-Ey elucidates, however, the nature of television production and consumption - and, in particular, the Soviets' decision to promote a home-based broadcasting system-put television in implicit conflict with important Soviet traditions, ideals, and, at times, interest groups. The development of the mature form of centralized Soviet television symbolized by Moscow's Ostankino complex is the story of how political and cultural elites, consumers, and the Soviet system in an abstract sense struggled to make a "home" for television technology in the USSR. 